\title{
Nervous System Development
}

National Cancer Institute

\section{Source}

National Cancer Institute. Nervous System Development. NCI Thesaurus. Code C26161.

Human Nervous System Development begins by differentiation of gastrula ectodermal cells into the neural plate, induced by signals from the mesoderm. Further development of this primordium forms the neural crest and neural tube. Neural crest cells become the peripheral nervous system while the neural tube forms the central nervous system. Cells in both structures differentiate into various glial cells and immature neurons that migrate; differentiate axons, dendrites, and synapses; and mature. 